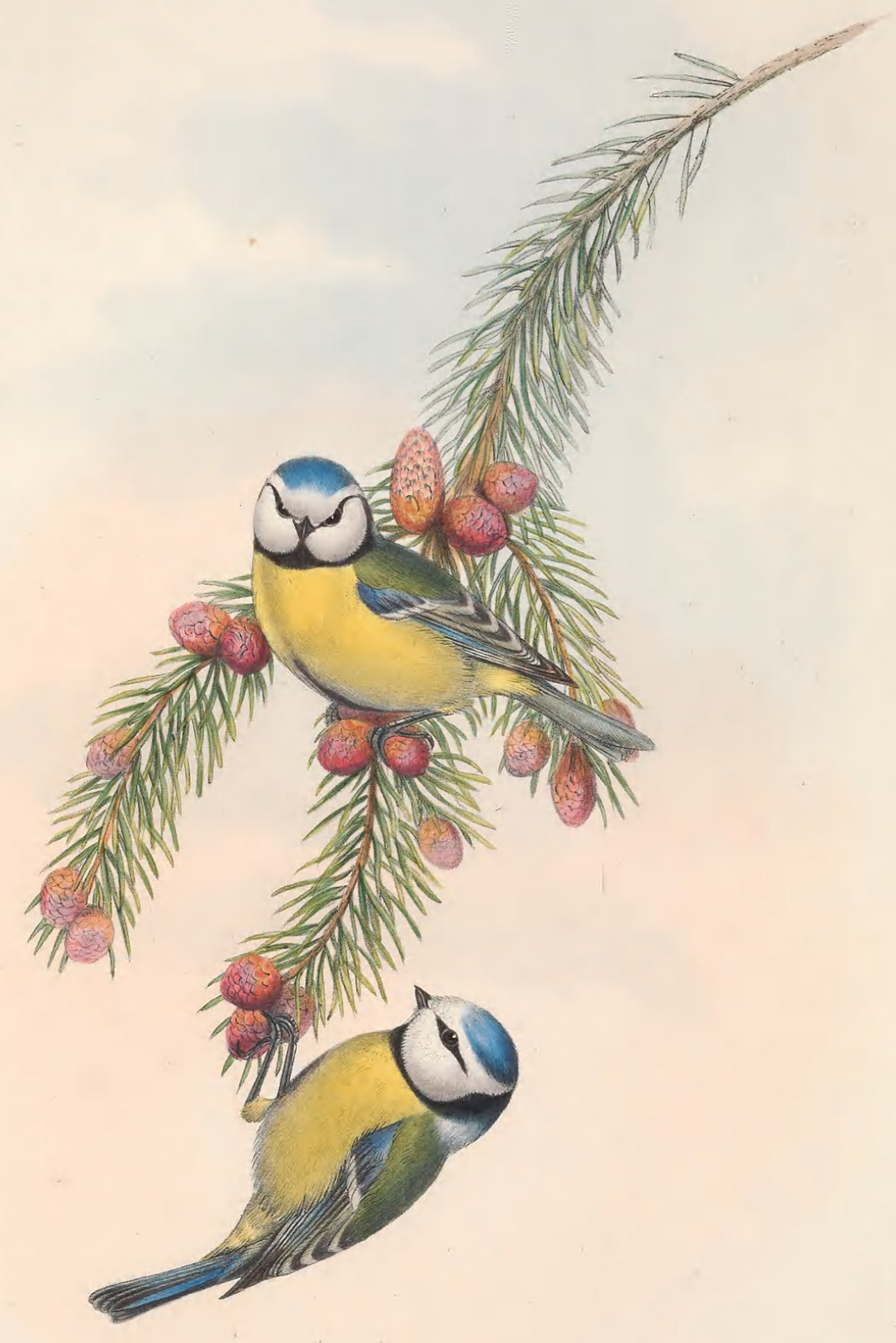




\section{PARUS CARULEUS.}

\section{Blue Tit.}

Parus caruleus, Linn. Syst. Nat., tom. i. p. 341.

Cyanistes caruleus, Kaup, Naturl. Sy.st., p. 99.

When a bird is so generally distributed over the British Islands that it is known to every school-boy, what can I say respecting it which has not been related before? Hackneyed descriptions become tiring to the reader, if incessantly repeated; while the presence of the little favourites themselves is always acceptable. Of these no one is better known or more welcome than the Blue Tit, which during the summer visits our gardens and rose-trees in search of the insects ensconced within the upcurled leaves, and which in winter, when the hoar frost puts it to certain straits, taps at our windows for a solitary sped house-fly or other insect on the inner side of the glass, or to solicit alms in the shape of crumbs or a picked bone. The child of the warm hearth within, naturally desirous of possessing it, sets his brick-trap on the snow; and the poor bird falls into the snare. Then comes the peck from its little sharp bill, and its flurry to escape, which perhaps it effects, with the loss of its tail. When the boy grows up to manhood, such desires no longer exist, and he now admires the bird in its freedom, and very properly affords it his protection for its good services.

Although I have spoken so highly of the Blue Tit, I fear my meed of praise must be qualified; for however pretty and interesting he may be, and great as may be the good he effects in the destruction of insect-life, on the other hand a grave offence is laid to his charge - that of pecking holes in our ripening apples and pears, when, the skin being broken, the wasp soon completes the destruction he has commenced. This is a serious matter; and it does not lessen the offence of the Blue Tit when I say that such conduct is common to all its brethren. This bird also, and indeed all the Tits, occasionally resorts in winter and early spring to the entrances of bee-hives, and carries off such of the insects as may have been induced by a sunny morning to come forth to seek for any opening flower.

That every bird has its own particular area, more limited with some than with others, must be well known. Europe generally is the portion of the globe where the Blue Tit is destined to dwell. And here, again, I must make use of the term "generally distributed;" for whether it be the countries of the south washed by the Mediterranean, or those bordering the Baltic in the north, the bird is a denizen of them all : on the one hand, it crosses the border-line to Sweden, Norway, and Finland, as far as the 63rd degree of north latitude; on the other hand, I have no evidence that, like so many other European birds, it ever crosses the Mediterranean to North Africa, its place there being supplied by the Parus ultramarinus.

As spring advances, the Blue Tit becomes pert and lively, and by its busy actions and flittings to and fro soon betrays the site it has selected for its intended nest: this may be a hole in a stunted willow, apple, or other tree, a split in the gate-post, a crack in the neighbouring wall, the spout of the garden-pump, or an inverted flower-pot. Wherever it may be, the nest is commenced in April ; and if left undisturbed, a numerous progeny fly off to the branches of the neighbouring trees, in the following month, and leave the parents a yet long summer to repeat the process and rear a second brood. Now come into play its useful qualities; for the number of caterpillars and perfect insects taken by a brood of ten or twelve young Tits is enormous. $\mathrm{Mr}$. Weir communicated to Mr. Macgillivray his observations on the feeding of the young in the nest, between a quarter past two in the morning and half past eight in the evening, and found that they do so in that period four hundred and seventy-five times, each time bringing one caterpillar, at others two or three; so that probably this one pair of birds destroyed six or seven hundred in the course of a single day. After such a statement as this, must we not be surprised how any one can question the usefulness of these little birds? for I can easily imagine that, but for them and other allied species, we should be so overrun by insects that the consequences would be frightful to contemplate. If our little birds are let alone, a proper balance between bird- and insect-life will be kept up, with a highly beneficial result ; and I cannot but believe that darkness reigned over that parish whose churchwardens' account contained an item for seventeen dozen tomtits' heads.

When insect-food becomes scarce, the bird may frequently be seen carrying about in its bill the seed of some tree, or a stone of the wild cherry, which it ultimately holds firmly between its toes on the horizontal branch of a tree, or places in a chink or interstice of the bark, and hammers at it with its little bill and all its might until a hole is made and the kernel reached. This hammering noise may often be heard in the woods; for it is made by all the Tits, as well as the more powerful Nut-hatch. 
Its saucy note, which is very frequently uttered, resembles the words chica-chica-chee-chee-chirr-r-r $r^{r}$; it also gives utterance to a more lengthened strain.

No bird sits more closely on its eggs; for, rather than desert them, the female will allow herself to be taken by the hand, and, if released, will return to the nest and continue the task of incubation; but immediately the young are hatched, she becomes fierce, and manifests unequivocal dislike to intrusion.

A nest taken at Taplow in May, 1859, was carelessly composed of fine wood-shavings interwoven with moss ; the interior was warmly lined with wool, hair, and feathers. The eggs, ten in number, before being blown, were of a dull fleshy white, spotted with reddish, and not so transparent as the eggs of small birds generally are; when emptied of their yelk, the ground-colour became of a beautiful opaque white.

The progeny of a nest generally keep together during the first autumn, and frequent the garden or shrubbery in which they were bred, but in winter range widely over the neighbouring woods, coppices, and hedgerows; early in the spring all that have escaped the natural enemies which interfere with their well-being separate into pairs and follow the example of their parents.

The colouring of the nestling birds is very singular, and quite different from that of the adults. The cheeks, the throat, the forehead, the back of the head, and the nape, which are all white in the old bird, are of a rich and beautiful yellow at this young age. This very striking character is common to the young of this species, the Coal-, and the Great Tit, but not to those of the Marsh-Tit. How long this yellow colouring is retained I do not know ; but that it is soon exchanged for the adult livery there can be little doubt, for in midwinter both adults and young are alike to a feather.

There is no outward difference in the appearance of the sexes; neither are they subject to any seasonal change.

The forehead, a line over the eye to the back of the crown, cheeks, and ear-coverts bluish white; line from the base of the bill through the eye to the occiput deep bluish black; crown of the head blue ; stripe down the centre of the throat, and a band which crosses the throat and passes upwards to the back of the head, deep prussian blue; back and upper tail-coverts light yellowish green; wing-coverts deep blue, the greater ones tipped with white; primaries slaty black, narrowly edged with pale greenish blue, fading into white on the apical portion of the longest feathers; secondaries bluish, narrowly margined and largely tipped with white; tail blue; under surface pale sulphur or greenish yellow, with a longitudinal stripe of prussian blue down the centre of the abdomen; margins of the wing-feathers white on the under surface; under side of the tail pearl-grey; bill dusky horn-colour; legs, toes, and claws bluish black.

The young nestlings have the same arrangement of the colours; but the forehead, line over the eye to the occiput, face, ear-coverts, and under surface are pure yellow, and they have also a band of yellow at the base of the neck behind; the gape, which is very wide and fleshy, is of a bright gamboge-yellow; the mandibles are yellow, clouded with reddish brown; inside of the mouth orange; legs and feet blue; round the eye a circle of naked bluish skin.

The Plate represents two adults of the natural size. 


\section{$2 \mathrm{BHL}$ Biodiversity Heritage Library}

Gould, John. 1873. "Blue Tit, Parus caeruleus [PI. 24]." The birds of Great Britain 2, -. https://doi.org/10.5962/p.323839.

View This Item Online: https://www.biodiversitylibrary.org/item/221554

DOI: https://doi.org/10.5962/p.323839

Permalink: https://www.biodiversitylibrary.org/partpdf/323839

\section{Holding Institution}

Smithsonian Libraries

\section{Sponsored by}

Biodiversity Heritage Library

\section{Copyright \& Reuse}

Copyright Status: Public domain. The BHL considers that this work is no longer under copyright protection.

This document was created from content at the Biodiversity Heritage Library, the world's largest open access digital library for biodiversity literature and archives. Visit BHL at https://www.biodiversitylibrary.org. 